\title{
EXPERIMENTAL INVESTIGATION OF CLAY-STRAW BUILDING FINISHING LAYER UNDER DIFFERENT DRYING CONDITIONS
}

\author{
${ }^{1}$ Tadas TAMOŠIŪNAS, ${ }^{2}$ Romas GIRKONTAS, ${ }^{3}$ Andrius SAVICKAS, \\ ${ }^{4}$ Šarūnas SKUODIS, ${ }^{5}$ Lumir MICA \\ ${ }^{1,4}$ Vilnius Gediminas Technical University, Department of Geotechnical Engineering, Vilnius, Lithuania \\ ${ }^{2,3}$ Vilnius Gediminas Technical University, Department of Steel and Timber Structures, Vilnius, Lithuania \\ ${ }^{5}$ Brno University of Technology, Department of Geotechnics, Veveri 95, Brno, 60200 Czech Republic
}

Received 29 March 2016; accepted 09 May 2016

\begin{abstract}
This manuscript represents investigation of six different clay mixtures under variable drying conditions, namely: bright yellow clay (typical for Lithuania), brown clay (Lithuania Sergènai district), mixture of different clays, white Spanish clay, clay mass which is resistant for thermal coldness (with synthetic cardigan) and Lithuanian coarse clay with granite additives. Drying process was provided imitating natural drying process and fast drying in drying oven at $110 \mathrm{C}^{\circ}$. The main idea of this study - imitate clay and clay-straw buildings drying process and to determine which of used clay types had smallest volumetric and linear deformations. Volumetric and linear deformations for clay-straw buildings is one of the most important factors evaluating cracking in this type of buildings. To reach this purpose six tiles of different clay types were used. Before drying stage water content, plasticity, and liquid limits index, respectively was determined for all types of clay. All clay tiles volumetric and linear deformations before and after drying process were measured with specialized view analysis program in order not to damage samples' form. According to the obtained results a clay type whith the smallest deforamations (volumetric and linear) was found. With the smallest volumetric and linear deformations clay-straw building is not only environmental friendly, sustainable and green, but it does not require a lot of maintenance during building life time.
\end{abstract}

Keywords: clay, clay-straw buildings, volumetric deformations, linear deformation, ecological buildings, $\mathrm{CO}_{2}$ emision.

\section{Introduction}

Nowadays more and more people choose to live in the clay-straw buildings. These buildings are environmentally friendly, whith main construction materials - clay and straw (Minke 2006). These buildings characterize according to their qualities: high quality for indoor environment (Yokobayashi, Sato 2015), hygrothermal properties (Labat et al. 2016; Miljan M., Miljan J. 2015), low cost (Gupta 2015), air tightness (Brojan et al. 2015) and one of the most important factors - materials which are used for these buildings do not have high impact for $\mathrm{CO}_{2}$ emissions increment. According to Gustavsson and Sathre (2006) analysis, the most aggressive materials for environment (highest $\mathrm{CO}_{2}$ emissions) are concrete and steel (Fig. 1).

Buildings which may be called ecological should provide more energy than it is necessary to use for the building. This type of buildings can be also called zero emission buildings (Sartori et al. 2012). The main concept of a zero emission building is that the renewable energy sources produced or transformed at the building site have to compensate for $\mathrm{CO}_{2}$ emissions (Gustavsson et al. 2010) from operation of the building and for production, transport and demolition of all the building materials and components during the life cycle of the building (Fig. 2.).

Corresponding author:

L. Mica E-mail: mica.l@fce.vutbr.cz 


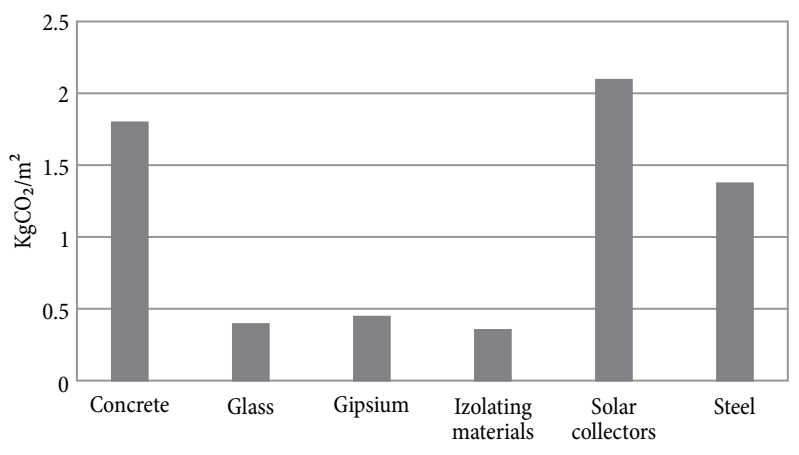

Construction materials

Fig. 1. $\mathrm{CO}_{2}$ emissions of the most popular construction materials

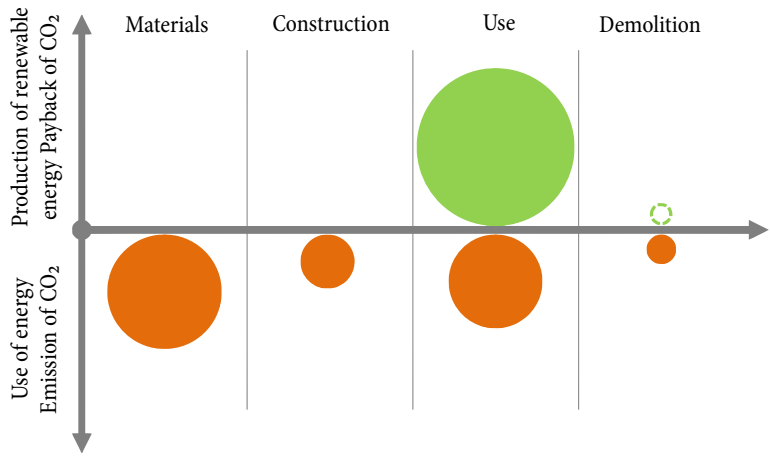

Fig. 2. Description of zero energy buildings

For clay, clay-straw and straw buildings the highest payback of renewable energy production is obtained in demolition stage (Seyfang 2010; Bribian et al. 2011), because mostly all construction materials are organic and environmentally friendly (Fig. 3).

Architecture of such structures is rapidly improving because of increasing demand of these buildings (Mansour et al. 2007; Walker 2004; Ashour et al. 2010; Girkontas et al. 2014; Torgal, Jalali 2012). According to geological conditions in Lithuania, there is an opportunity to explore different clay types and colors (Weismann, Bryce 2015) for clay and clay-straw buildings finish (Fig. 4). Clay from different deposites has different deformation properties (Minke 2006). Due to this reason, purpose of this manuscript is to determine clays deformation affected by different drying temperatures and to compare obtained deformations. According to comparison results we strive to determine clay with smallest deformations.

\section{Determination of physical clay parameters}

In this study 6 different clays are used, namely: bright yellow clay (typical for Lithuania), brown clay (Lithuania Sergenai district), mixture of different clays, white

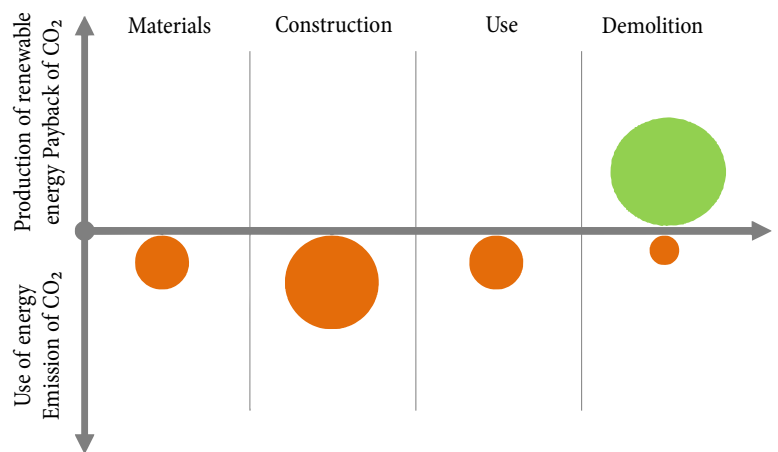

Fig. 3. Clay, clay-straw or straw buildings energy description

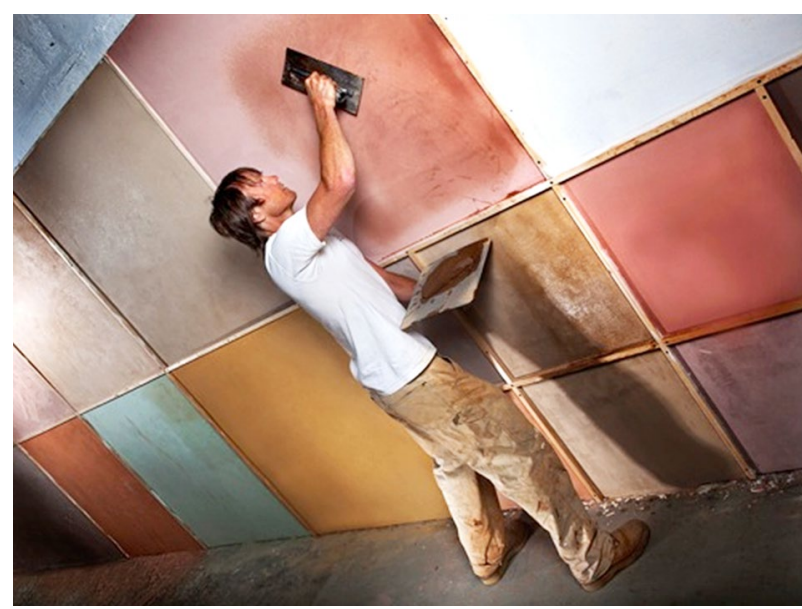

Fig. 4. Clay wall finish layer variance (Weismann, Bryce 2006)

Spanish clay, clay mass which is resistant for thermal coldness (with synthetic cardigan), and Lithuanian coarse clay with granite additives (Fig. 5).

For examined clays (Fig. 5) Atterberg limits (Amšiejus et al. 2006; Medzvieckas et al. 2004), plasticity index and liquidity index (LST EN ISO 146881:2007) were determined and they are shown in Figures 6 and 7.
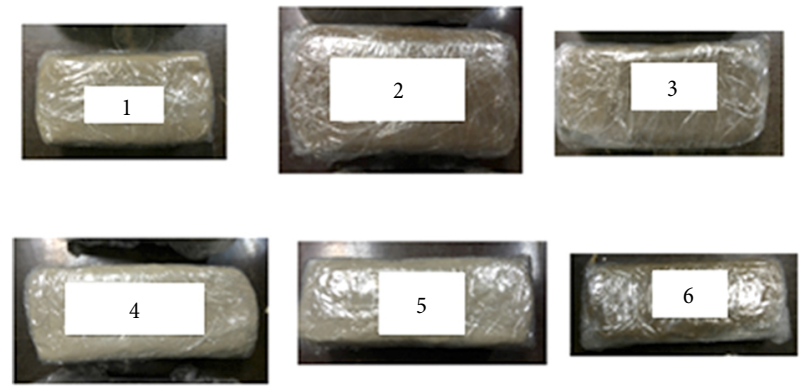

Fig. 5. Tested clays in the study: 1. Bright yellow clay (typical for Lithuania); 2. Brown clay (Lithuania Sergenai district); 3. Mixture of different clays; 4 . White Spanish clay; 5. Clay mass which is resistant for thermal coldness (with synthetic cardigan); 6. Lithuanian coarse clay with granite additives 


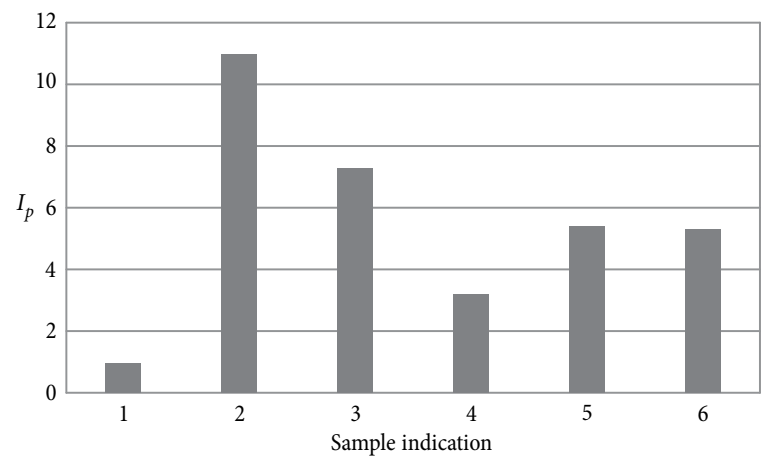

Fig. 6. Plasticity index of examined clays: 1 - bright yellow clay (typical for Lithuania); 2 - brown clay (Lithuania Sergènai district); 3 - mixture of different clays; 4 - white Spanish clay; 5 - clay mass which is resistant for thermal coldness (with synthetic cardigan); 6 - Lithuanian coarse clay with granite additives

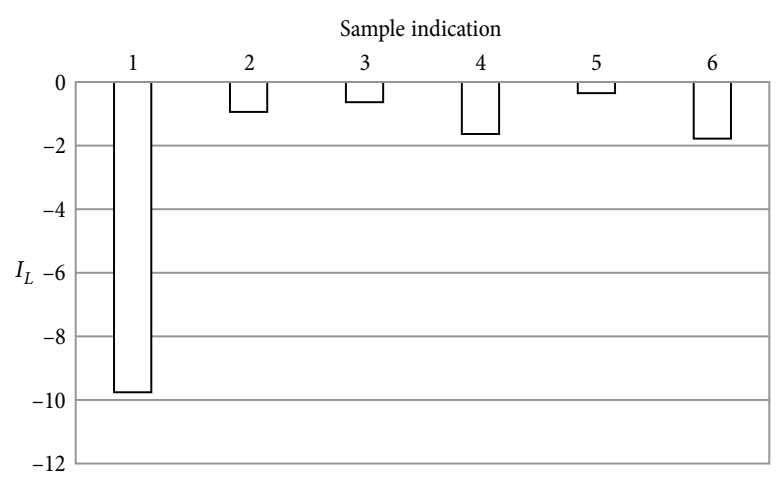

Fig. 7. Liquidity index of examined clays: 1 - bright yellow clay (typical for Lithuania); 2 - brown clay (Lithuania Sergenai district); 3 - mixture of different clays; 4 - white Spanish clay; 5 - clay mass which is resistant for thermal coldness (with synthetic cardigan); 6 - Lithuanian coarse clay with granite additives
Analyzing Figure 6 it was obtained, that bright yellow clay has a very small difference between plastic and liquid limits. Brown clay plastic and liquid limits has the biggest difference between each other. Liquidity index, which is shown in Figure 7 has a negative values, because for all speciments it was obtained low water content values which are smaller than plastic limits water content. The biggest liquidity index was obtained for bright yellow clay, the smallest - clay mass which is resistant for thermal coldness (with synthetic cardigan).

\section{Determination of volumetric deformations}

All clay samples were examined under two drying conditions: 1) Natural drying conditions $+15{ }^{\circ} \mathrm{C}$, drying time equals to $168 \mathrm{~h}$, after this drying stage each sample was dried in drying oven $\left(+110^{\circ} \mathrm{C} 4 \mathrm{~h}\right)$, in order to reach $0 \%$ water content; 2 ) Prepared samples dried in the oven at $+110^{\circ} \mathrm{C}$ for 4 hours. All in different drying conditions obtained results are given in Table 1. Clay number given in this table is the same clay indication as in Figures 6 and 7.

Analyzing obtained volumetric deformations results it can be concluded that volumetric deformations of examined clays tiles are related with drying conditions. Obtained differences of volumetric deformations according to two different drying conditions are not the same for each examined clay tile. Most sensitive tiles with largest volumetric deformations according to volumetric deformations difference (see Table 1) are made from mixture of different clays (clay no. 3 ).

Table 1. Volumetric deformations of examined clay tiles

\begin{tabular}{|c|c|c|c|c|c|c|c|c|c|c|}
\hline \multirow{2}{*}{$\begin{array}{l}\text { Clay } \\
\text { No. }\end{array}$} & \multirow{2}{*}{$\begin{array}{c}\text { Drying } \\
\text { conditions }\end{array}$} & \multicolumn{4}{|c|}{ Tile with natural water content } & \multicolumn{4}{|c|}{ Dry tile } & \multirow[t]{2}{*}{$\mathrm{V}_{\mathrm{w}}-\mathrm{V}_{\mathrm{d}}, \%$} \\
\hline & & $\mathrm{L}_{\mathrm{w}}, \mathrm{mm}$ & $\mathrm{B}_{\mathrm{w}}, \mathrm{mm}$ & $\mathrm{t}_{\mathrm{w}}, \mathrm{mm}$ & $\mathrm{V}_{\mathrm{w}}, \mathrm{mm}^{3}$ & $\mathrm{~L}_{\mathrm{d}}, \mathrm{mm}$ & $\mathrm{B}_{\mathrm{d}}, \mathrm{mm}$ & $\mathrm{t}_{\mathrm{d}}, \mathrm{mm}$ & $\mathrm{V}_{\mathrm{d}}, \mathrm{mm}^{3}$ & \\
\hline \multirow[t]{2}{*}{1} & 1 & 147.50 & 80.00 & 11.00 & 129800.00 & 140.69 & 75.66 & 8.72 & 92820.96 & 28.49 \\
\hline & 2 & 148.00 & 83.50 & 11.50 & 142117.00 & 142.81 & 77.72 & 9.20 & 102112.58 & 28.15 \\
\hline \multirow[t]{2}{*}{2} & 1 & 147.50 & 79.00 & 11.00 & 128177.50 & 143.36 & 76.14 & 10.25 & 111883.16 & 12.71 \\
\hline & 2 & 149.00 & 78.00 & 10.50 & 122031.00 & 148.04 & 76.70 & 8.36 & 94925.02 & 22.21 \\
\hline \multirow[t]{2}{*}{3} & 1 & 149.00 & 77.00 & 10.00 & 114730.00 & 143.31 & 76.84 & 8.94 & 98446.75 & 14.19 \\
\hline & 2 & 152.00 & 78.50 & 10.50 & 125286.00 & 144.12 & 76.81 & 8.08 & 89444.45 & 28.61 \\
\hline \multirow[t]{2}{*}{4} & 1 & 149.00 & 80.00 & 10.50 & 125160.00 & 143.99 & 78.39 & 10.32 & 116485.72 & 6.93 \\
\hline & 2 & 147.00 & 81.50 & 11.50 & 137775.75 & 144.61 & 78.28 & 10.31 & 116709.93 & 15.29 \\
\hline \multirow[t]{2}{*}{5} & 1 & 147.50 & 78.50 & 11.00 & 127366.25 & 139.98 & 77.76 & 10.35 & 112658.14 & 11.55 \\
\hline & 2 & 152.00 & 80.00 & 9.50 & 115520.00 & 146.93 & 77.21 & 7.93 & 89961.61 & 22.12 \\
\hline \multirow[t]{2}{*}{6} & 1 & 148.00 & 77.50 & 10.50 & 120435.00 & 144.56 & 73.21 & 9.31 & 98529.94 & 18.19 \\
\hline & 2 & 145.00 & 74.50 & 13.00 & 140432.50 & 139.92 & 72.32 & 9.90 & 100178.24 & 28.66 \\
\hline
\end{tabular}


Lowest sensitivity for drying conditions is obtained for bright yellow clay (typical for Lithuania, see Table 1 clay no. 1).

\section{Determination of linear deformations}

In order not to damage clay tiles with measuring equipment, linear deformations were determined with optical microscope view analysis program (Skuodis, Šlečkuvienè 2014). In this case it is necessary to make a photo of investigated clay tile with measuring scale (Fig. 8). Obtained linear deformations results are given in Table 2. In all tested clay tiles any cracks or crushes did not happen as for Qiang et al. 2014 and Burst 1965.

The biggest obtained linear deformation was for clay tiles made of white Spanish clay and the smallest linear deformations was for clay tiles made of bright yellow clay (typical for Lithuania) and Lithuanian coarse clay with granite additives.

\section{Conclusions}

A series of different clay tiles volumetric and linear deformations tests were conducted according to different drying conditions. Analysis of deformations differences revealed clay types which had smallest and largest volumetric and linear deformations. Following findings were drawn from this study:

1. For clay tiles, which had higher $I_{P}$ difference under different drying conditions (per all drying period), volumetric and linear deformations is increasing.

2. Drying conditions had more influence on the volumetric deformations than on the linear ones.

3. Clay tiles which were made from Lithuanian clay had $54-79 \%$ smaller deformations than those made of Spanish clay.

4. It is suggested to use Lithuanian clay for clay house wall finish because in this case smaller volumetric and linear deformations happen and due to a short transportation distance $\mathrm{CO}_{2}$ emissions are reduced.

Table 2. Linear deformations of examined clay tiles

\begin{tabular}{|l|c|c|}
\hline \multirow{2}{*}{\multicolumn{1}{|c|}{ Clay tile }} & \multicolumn{2}{c|}{ Linear deformation, \% } \\
\cline { 2 - 3 } & Natural drying conditions & Drying in the oven \\
\hline Bright yellow clay (typical for Lithuania) & 2.86 & 2.49 \\
\hline Brown clay (Lithuania Sergènai district) & 1.72 & 3.72 \\
\hline Mixture of different clays & 4.7 & 2.98 \\
\hline White Spanish clay & 3.14 & 5.16 \\
\hline Clay mass which is resistant for thermal coldness (with synthetic cardigan) & 4.7 & 3.47 \\
\hline Lithuanian coarse clay with granite additives & 2.17 & 2.97 \\
\hline
\end{tabular}
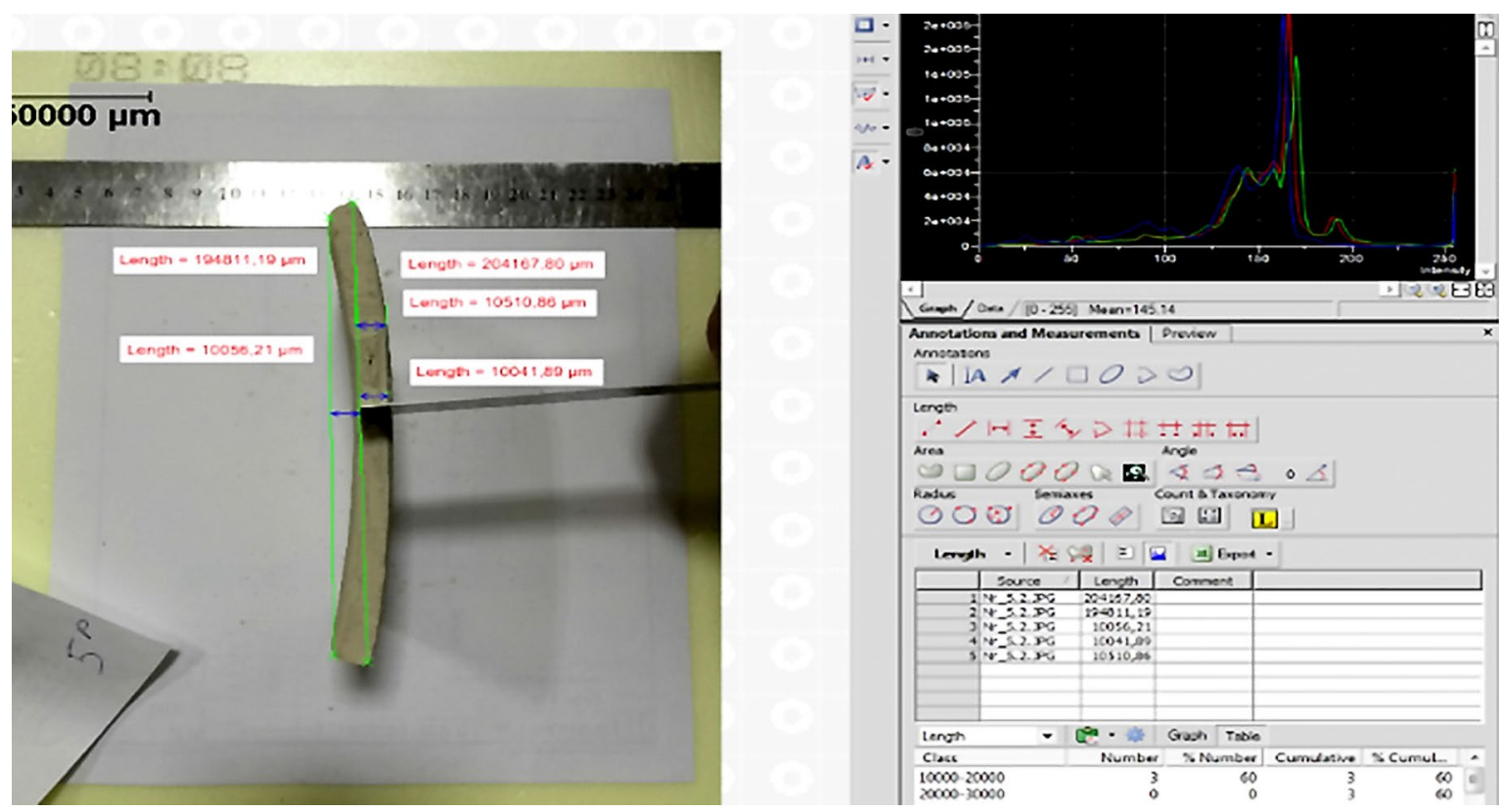

Fig. 8. Determination of linear deformations with view analysis program 


\section{Acknowledgements}

An equipment and infrastructure of Vilnius Gediminas Technical University of Civil Engineering Research Centre was employed for investigations.

\section{References}

Amšiejus, J.; Mackevičius, R.; Medzvieckas, J.; Sližytė, D.; Stragys, V. V. 2006. Gruntu fizinès ir mechaniness savybès, Laboratoriniai darbai [Soil physical and mechanical properties, Laboratory testing]. Vilnius: Technika. $164 \mathrm{p}$.

Ashour, T.; Wieland, H.; Georg, H.; Bockisch, F. J.; Wu, W. 2010. The influence of natural reinforcement fibres on insulation values of earth plaster for straw bale buildings, Materials \& Design 31(10): 4676-4685.

http://dx.doi.org/10.1016/j.matdes.2010.05.026

Bribian, I. Z.; Capilla, A. V.; Uson, A. A. 2011. Life cycle assesment of building materials: Comparative analysis of energy and environmental impacts and evaluation of the eco-efficieny improvement potential, Building and Environment 46(5): 1133-1140. http://dx.doi.org/10.1016/j.buildenv.2010.12.002

Brojan, L.; Weil, B.; Clouston, P. L. 2015. Air tightness of straw bale construction, Journal of Green Building 10(1): 99-113. http://dx.doi.org/10.3992/jgb.10.1.99

Burst, J. F. 1965. Subaqueously formed shrinkage cracks in clay, Journal of Sedimentary Research 35(2): 348-353.

Gupta, M. S. 2015. Straw bale construction a revolutionary building material in low cost housing for rural areas, International Jounal of Recent Advances in Multidiscilinary Research 2(7): 583-587.

Gustavsson, L.; Joelsson, A.; Sathre, R. 2010. Life cycle primary energy use and carbon emission of an eight-storey woodframed apartment building, Energy and buildings 42(2): 230-242. http://dx.doi.org/10.1016/j.buildenv.2005.04.008

Girkontas, R.;Tamošiūnas, T.; Savickas, A. 2014. Research of deformation of clay soil mixtures, Science - Future of Lithuania 6(5): 488-492.

Gustavsson, L.; Sathre, R. 2006. Variability in energy and carbon dioxide balances of wood and concrete building materials. Building and Environment 41(7): 940-951.

Yokobayashi, S.; Sato, M. 2015. Estimation of indoor environment of a Tsuchikabe house constructed by Japanese Sakan craftsmen, in 6th International Building Physics Conference, Energy Proceedia 78(2015): 2814-2819.

Labat, M.; Magniont, C.; Oudhof, N.; Aubert, J. E. 2016. From the experimental characterization of the hygrothermal properties of straw-clay mixtures to the numerical asssesment of their buffering potential, Building and Environment 97(2016): 69-81.

http://dx.doi.org/10.1016/j.buildenv.2015.12.004
LST EN ISO 14688-1:2007 lt. Geotechniniai tyrinejimai ir bandymai. Gruntų atpažintis ir klasifikavimas. 1 dalis. Atpažintis ir aprašymas [Geotechnical investigation and testing - Identification and classification of soil - Part 1: Identification and description]. LSD 2007. $14 \mathrm{p}$.

Mansour, A.; Srebic, J.; Burley, B. J. 2007. Development of strawcement composite sustainable building material for low-cost housing in Egypt, Journal of Applied Sciences Research 3(11): 1571-1580.

Medzvieckas, J.; Sližytė, D.; Stragys, V. 2004. Soil mechanics. Laboratory testing manual. Vilnius: Technika. $79 \mathrm{p}$.

Miljan, M.; Miljan, J. 2015. Thermal transmittance and the embodied energy of timber frame lightweight walls insulated with straw and reed, Materials Science and Engineering 96(2015): 1-7.

http://dx.doi.org/10.1088/1757-899x/96/1/012076

Minke, G. 2006. Building with earth. Design and technology of a sustainable architecture. $198 \mathrm{p}$.

Qiang, X.; Hai-jun, L.; Zhen-ze, L.; Lei, L. 2014. Cracking, water permeability and deformation of compacted clay liners improved by straw fiber, Engineering Geology 178: 82-90. http://dx.doi.org/10.1016/j.enggeo.2014.05.013

Sartori, I.; Napolitano, A.; Voss, K. 2012. Net zero energy buildings: a consistent definition framework, Energy and Buildings 48(2012): 220-232. http://dx.doi.org/10.1016/j.enbuild.2012.01.032

Seyfang, G. 2010. Community action for sustainable housing: Building a low-carbon future, Energy Policy 38(12): 76247633. http://dx.doi.org/10.1016/j.enpol.2009.10.027

Skuodis, Š.; Šlečkuvienè, A. Smèlinių gruntų dalelių vaizdų analizè skanuojančiu elektroniniu mikroskopu [Sand soil grains view analysis via scaning electronic microskope], in Proceedings of the 17th Conference for Junior Researchers "Science Future of Lithuania”, 2014, Vilnius, Lithuania.

Torgal, F.; Jalali, S. 2012. Earth construction: Lessons from the past for future eco-efficient construction, Construction and Building Materials 29(2012): 512-519.

http://dx.doi.org/10.1016/j.conbuildmat.2011.10.054

Walker, P. J. 2004. Strength and erosion characteristics of earth blocks and earth block masonry, Journal of Materials in Civil Engineering 16: 497-506. http://dx.doi.org/10.1061/(ASCE)0899-1561(2004)16:5(497)

Weismann, A.; Bryce, K. 2006. Building with cob a step-by-step guide. $256 \mathrm{p}$.

Weismann, A.; Bryce, K. 2015. Clay and lime renders, plasters and paints a how-to guide to using natural finishes. $264 \mathrm{p}$. 
Tadas TAMOŠIŪNAS is a graduate student of geotechnical engineering master studies in Vilnius Gediminas Technical University. Research interests: geotechnical engineering, engineering geology, soil mechanics.

Romas GIRKONTAS is a formerly graduate student with the degree of Master of science in civil engineering at Vilnius Gediminas Technical University. Research interests: civil engineering, FEM, geotechnical engineering.

Andrius SAVICKAS is a formerly graduate student with the degree of Master of science in civil engineering at Vilnius Gediminas Technical University. Research interests: civil engineering, geotechnical engineering, analysis and design of structures, mechanical stability.

Šarunas SKUODIS, Dr. Lecturer at the Department of Geotechnical Engineering, Vilnius Gediminas Technical University (VGTU), Lithuania. Research interests: modeling mechanical properties of soil, soil - structure interaction, foundation engineering.

Lumir MIČA, Head of Institute of Geotechnics, Assoc. Prof. Research interests: soil improvement, soil reinforcement, application of numerical method in geotechnics. 